\title{
Marek Sioma
}

(Maria Curie-Skłodowska University in Lublin, Poland)

https://orcid.org/0000-0002-4222-7719

E-mail: marek.sioma@poczta.umcs.lublin.pl

\section{'Borderline on Fire' - the Film Image of the Polish Inter-War Period as an Element of Public Discourse}

\author{
'Pogranicze w ogniu' - filmowy obraz polskiego dwudziestolecia \\ międzywojennego, jako element dyskursu publicznego
}

\begin{abstract}
Focusing on a 24-episode TV drama series Borderline on Fire, the presented text offers an analysis of the long-lasting discussion of both the series and the Second Republic of Poland with which the series is bound up. The main goal I set myself in writing the article was to show the significance of the inter-war era - which is inseparably associated with the person of Józef Piłsudski and which has been the subject of much mythologization - in public discourse. The article supports the conclusion that the inter-war period still attracts much interest, especially among history-lovers, and that the series dealt with in it can be considered to be one of the factors to which the epoch owes this interest.
\end{abstract}

\begin{tabular}{|c|c|c|c|c|}
\hline \multicolumn{5}{|c|}{ PUBLICATION INFO } \\
\hline (IH) & UIMCS & * & $\begin{array}{l}\text { e-ISSN: } 2449-8467 \\
\text { ISSN: } 2082-6060\end{array}$ & ACCESS \\
\hline \multicolumn{5}{|c|}{$\begin{array}{l}\text { THE AUTHOR'S ADDRESS: Marek Sioma, the Institute of History of the Maria Curie-Skłodowska University in } \\
\text { Lublin, 4A Maria Curie-Skłodowska Square, Lublin 20-031, Poland }\end{array}$} \\
\hline \multicolumn{5}{|c|}{$\begin{array}{l}\text { SOURCE OF FUNDING: Statutory Research of the Institute of History of the Maria Curie-Skłodowska University } \\
\text { in Lublin }\end{array}$} \\
\hline \multicolumn{2}{|l|}{$\begin{array}{l}\text { SUBMITTED: } \\
2019.07 .16\end{array}$} & $\begin{array}{l}\text { ACCEPTED: } \\
2020.01 .14\end{array}$ & $\begin{array}{l}\text { PUBLISHED ONLINE: } \\
2020.12 .28\end{array}$ & \\
\hline \multicolumn{3}{|c|}{$\begin{array}{l}\text { WEBSITE OF THE JOURNAL: } \\
\text { https://journals.umcs.pl/rh }\end{array}$} & $\begin{array}{l}\text { EDITORIAL } \\
\text { COMMITTEE E-mail: } \\
\text { reshistorica@umcs.pl }\end{array}$ & ossref \\
\hline
\end{tabular}


Key words: Andrzej Konic, Second Republic of Poland, historical TV drama series, inter-war period, Polish-German relations, politics of history, discourse, Second Department of Polish General Staff, Abwehr

The dispute over the use of history is as old as history itself. The past, or actually knowledge about it, has been used for particularist political interests since the year dot. This appears, by the way, to be also an immanent trait of the human being, especially of the homo politicus. History is used by every political authority, with differences in terms of the scale of that use and articulated accents. Besides, they are determined by the political orientation. This thread is not worth continuing (especially in the era of such a deep political division of the Polish society); however, it should be pointed out that the notion of politics of history has not only become entrenched in the ruling circles (elites), but it has found its place in the - broadly understood - society ${ }^{1}$. At the same time, there is no doubt that everybody understands them differently, adjusting the encyclopedic definition $^{2}$ to their own beliefs and needs. It is also used, in a number of ways, in current politics. The author's goal is not to participate in the discussion - even though it may turn out to be wishful thinking - but to show how the title series was presented in the public discourse, how and to what extent it influenced the perception and, consequently, the popularization of knowledge on the Second Polish Republic.

From the point of view of the scientific analysis of the series, it is worthwhile to recall the words of Andrzej Paczkowski who, in one of

1 Tomasz Merta pointed out that history cannot be rejected a priori as a building block of political capital, as long as its assumed role is to build the political capital of a nation, not of a political party. As he argued: 'Wszystko źle lub w nadmiarze stosowane jest albo niebezpieczne, albo niezdrowe, albo przynajmniej tuczące. Z polityką historyczną wiążą się dwa zasadnicze niebezpieczeństwa. Pierwsze - to uznać, że taka sfera nie istnieje, że wszystko się dzieje w sposób naturalny, że historycy zajmują się historia, a politycy polityką. Drugie - uznać, że polityka historyczna jest przeciwieństwem prawdy historycznej' ['Anything used wrongly or excessively is either dangerous, unhealthy, or at least fattening. There are two fundamental dangers connected with politics of history. One of them is to think that such a sphere does not exist, everything happens naturally, historians deal with history and politicians deal with politics. The other one is to consider historical politics the opposite of historical truth']. As quoted in: S. Chutnik, Czas honoru jako poppolityka historyczna, in: Seriale w kontekście kulturowym. Historia i polityka, eds. M. Cuchmińska, A. Naruszewicz-Duchlińska, Olsztyn 2014, pp. 13-14. The first version of the text was published on the 'Krytyka Polityczna' website (15 April 2010); however, the website was not active on in October 2017.

2 The most popular web 'encyclopadia' states that politics of history (German: Geschichtspolitik), or the politics of memory, is a process of shaping the awareness of history and strengthening the public discourse about the past. See: https://pl.wikipedia.org/wiki/ Polityka_historyczna [accessed on: 1 V 2019]. 
the interviews, quite accurately stated that 'getting to know the past is an important part of patriotism and an element of civic education' ${ }^{\prime 3}$. In his opinion, the image of the past created by many national cinematographies (German, Japanese or French) was a sugar-coated and episodic version of history. It is quite appropriate to say that Poland does not differ much, in this respect, from the abovementioned countries, following the trend of 'shredding' and powdering its own history. Nevertheless, historical cinema is in constant evolution, following new fashions. Initiated by Italians in the mid-1940s, documentary realism remains visible in numerous cinematographies to this day. Historical realities can be seen, inter alia, in American cinema, where there has been a shift towards showing 'the real reality', as Kazimierz Bartel used to say. Do we observe a similar phenomenon in Poland? In this matter, we can and even should have doubts, as few Polish historical series have met the criteria of historical realism so far. Notable exceptions include Columbuses [Kolumbowie] directed by Janusz Morgenstern, and Andrzej Wajda's full-length The Promised Land [Ziemia obiecana]. Here, it should be pointed out that few historical series are produced in Poland, which is probably due to the lack of money, as we have no shortage of motifs from our glorious - or not so glorious - history. Therefore, it is hard to resist the impression that, on the level of a historical series, we are still prisoners of a fairy tale unchangeably involving the evil one (a stranger, somebody different) and the good one (one of us). This is by no means an immanent feature of Polish artists. Such 'merchandise' sells much better, especially when combined with 'national' stereotypes. Apparently, the time of Polish historical series (strong, brutal, but truthful to the core) is yet to come, which A. Paczkowski summed up by saying: 'This is how national education works: something is idealized,

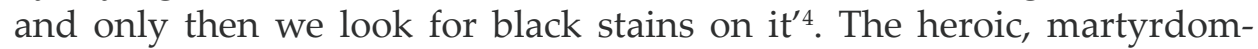
centered, self-absorbed narrative still prevails ${ }^{5}$. It remains to be hoped

\footnotetext{
3 'poznanie przeszłości jest ważną częścią patriotyzmu i elementem wychowania obywatelskiego'. Najpierw 'Czas honoru' potem czas na czarne plamy [Interview with Andrzej Paczkowski], 'Gazeta Wyborcza' 29 November 2013, p. 27; Sylwia Chutnik, analysing Czas honoru, stated that: 'efekt końcowy [serialu - M.S.] wpisuje się w strategię polityki historycznej rozumianej jako budowanie wspólnej tożsamości na bazie przeszłości' ['the final result [of the series - author's note] fits into the strategy of politics of history, understood as building of a common identity on the basis of the past']. See: S. Chutnik, op. cit., p. 10.

4 'Na tym polega narodowa edukacja - coś się idealizuje, a dopiero potem szuka czarnych plam'. Najpierw, p. 26.

5 It would be hard to disagree with Sylwia Chutnik that 'upiększanie rzeczywistości jest jedną z zasad kultury popularnej, do której należy przecież Czas honoru' ['embellishing reality is one of the principles of popular culture, to which Time of Honour belongs, after
} 
that the proportions will be reversed in the future and we will see at least a few series showing the past on a world-class level. Undoubtedly, this is not an easy task and, above all, not a cheap one either. It also requires an appropriate theme, but is fully viable. As an example, it is enough to mention the defense of Wizna - an episode of the German-Polish war in 1939, in which 720 Polish soldiers and officers under the command of Cpt. Władysław Raginis showed exceptional heroism. The Swedish music group Sabaton recorded a song entitled 'Battle of Wizna' about it; however, that episode on a scale of the Greek Thermopylae remains virtually unknown.

According to A. Paczkowski, 'we should constantly make different attempts to diversify the picture, to show the other party's motives and reasons ${ }^{\prime 6}$. It is hard to disagree with the eminent historian's constatation. However, considering that Borderline on Fire [Pogranicze wogniu $]^{7}$ (the series chronologically earlier) received much more flattering reviews ${ }^{8}$ than the later (second decade of the 21st century) Time of Honour [Czas honoru $]^{9}$, the analysis leads to the conclusion that good things have already happened. Lucjan Strzyga even said ruthlessly that 'compared to today's shreds for semi-intellectuals, the series directed by Andrzej Konic [thus also Borderline on Fire - author's note] seem like massive transatlantic ships, attracting crowds of nerds to the screens to this day ${ }^{\prime 10}$. If we assume

all']. See: S. Chutnik, op. cit., p. 14. It should be noted, however, that such a statement should not be the driving force for future scriptwriters and directors of film productions based on historical events.

6 'powinniśmy stale podejmować różne próby, żeby zróżnicować obraz, pokazać motywy i racje drugiej strony'. Najpierw, p. 27.

7 Originally, the series was to be titled The Burning Borderline. See: Ośrodek Dokumentacji i Zbiorów Programowych TVP S.A. Dział Dokumentacji Aktowej [hereinafter: ODiZP TVP], Państwowa Jednostka Organizacyjna ‘Polskie Radio i Telewizja' w Likwidacji [hereinafter: PJO], ref. no. 2149/30, vol. 22, no pagination, Recenzja scenariuszy serialu telewizyjnego pt. Płonace pogranicze autorstwa Mariana W. Jurka.

8 T. Formicki, 'Pogranicze w ogniu', czyli legenda wielkiej 'Dwójki', 'Myśl Polska' 12 October 2008, pp. 16-17.

9 Najpierw, pp. 26-27; Sylwia Chutnik presented a different approach, stating, inter alia, that the series included hyperrealism and toughening of the scenes 'podobne do zabiegów Quentina Tarantino (szczególnie chodzi tu o film Bękarty wojny), ale bez jego ironii i subwersji oraz wyestetyzowanej brutalności, która jest rewersem przemocy w wydaniu abject' ['similar to the work of Quentin Tarantino (especially in the film Inglourious Basterds), but without his irony, subversion or aestheticied brutality, which is the reverse of the abject violence']. See: S. Chutnik, op. cit., p. 12.

10 ‘w porównaniu $\mathrm{z}$ dzisiejszą serialową drobnicą dla półinteligentów seriale reżyserowane przez Andrzeja Konica [a więc i Pogranicze w ogniu - M.S.] jawią się niczym imponujące transatlantyki, do dziś ściągające przed ekrany rzesze maniaków'. L. Strzyga, Kulisy serialowych przebojów reżysera Andrzeja Konica, in: http://www.gazetawroclawska.pl/ 
this highly critical opinion to be shared by others, then the time of the People's Republic of Poland was not a time wasted for historical series directed by A. Konic. The only question is whether this statement, taken somewhat out of context, proves A. Konic's series (e.g. to be so good technically and artistically, or those produced after the 'era' of Borderline on Fire ${ }^{11}$ to be so unelaborated? (e.g. Time of Honour). The answer is not unequivocal, as the parameters intended to measure them do not appear to be comparable ${ }^{12}$. In addition, a question arises what series, and how, should be compared. Should the epoch or the leitmotif e.g. the intelligence gameplay seen in Borderline on Fire, be the main criterion? Thirdly, are there any valid reasons for comparing series created in different political times? It seems that a positive answer poses, at the same time, a difficult task for the analysts. Not only have the political realities changed; so have the technical possibilities, and even the manner of acting. It is therefore difficult to formulate the most important criterion of evaluation. It will be the 'human factor' (the acting level) for some, context for others. Borderline on Fire is worth recalling one of the opinions from the period of its television broadcast, in which the author wrote: 'The series does not contain too many episodes - or even sequences - that impress visually. Borderline on Fire focuses on a duel of brains. The goal is not to kill the enemy or put them in prison, but to give the Germans false information ${ }^{\prime 13}$. It should also

artykul/324957,kulisy-serialowych-przebojow-rezysera-andrzeja-konica,id,t.html [accessed on: 20 V 2019].

11 Krzysztof Głogowski noted that, in Borderline on Fire, A. Konic showed 'bardzo korzystną przemianę $\mathrm{w}$ postawie twórczej samego Konica' ['a very favourable metamorphosis in the creative attitude of Konic himself'], associated with a different approach to the Germans than in More than Life at Stake [Stawka większa niż życie]. In his opinion, 'Konic, obdarzony chyba największym talentem reżysera filmów sensacyjnych wśród naszych twórców wyrzekł się tej irytującej, infantylnej maniery' ['Konic, endowed with perhaps the greatest spy film directing talent among our filmmakers, renounced that irritating, infantile manner']. See: K. Głogowski, Duchowa siła armii, 'Polska Zbrojna' 1 October 1992, p. 2.

12 Lucjan Strzyga stated that: 'Ze śmiercią Andrzeja Konica skończyła się epoka wielkich, wystawnych seriali telewizyjnych, którymi włodarze PRL-u demonstrowali światu swoją potęgę. Na ówczesne tasiemce nie żałowano pieniędzy, pokazywali się w nich popularni aktorzy, majstrowali przy nich spece od pokazywania historii przez odpowiednio spreparowany ideologiczny filtr' ['The death of Andrzej Konic marked the end of the era of great, lavish TV series, which the authorities of the Polish People's Republic would use to demonstrate their power to the world. No money was spared on long-winded productions of the time, starring popular actors and tinkered with by specialists in showing history through a suitably prepared ideological filter']. See: L. Strzyga, op. cit.

${ }_{13}$ 'Niewiele jest w serialu odcinków - a nawet sekwencji - efektownych w sensie wizualnym. Pogranicze w ogniu koncentruje się na pojedynku mózgów. Chodzi nie o to, by 
be noted that the common feature of Polish series from both political eras has been their use in the politics of history. That was also the goal seen in Borderline on Fire. In one of the documents from the mid-1980s, it was even stated that 'this is a piece of history of the Commonwealth's struggle against German expansionism, presented in a detective-story convention and selective manner through the prism of a fight of intelligence services. The script is based on real events of the 1920s; however, it is neither a simple reconstruction of events nor a para-document ${ }^{\prime 14}$. On the other hand, the reviewers of the script of the first ten episodes saw in the series a 'warning against the German threat', noticing the preventive role it was to play in the context of slogans of West German imperialism and revanchism ${ }^{15}$. Undoubtedly, that was also how the message was perceived by the reviewers from the Ministry of the Interior, who found 'considerable patriotic and educational values' in the series ${ }^{16}$.

Returning to general issues, it can be assumed that, in the assessment of productions concerning and using history, the person closest to the truth was most likely Bogusław Wołoszański who argued that 'the main thing is to make historical films that arouse discussions. Because history is then alive ${ }^{\prime 17}$. Let us add that an equally important question is to reach numerous and age-diverse audience. When historical knowledge is not popularized, the society undoubtedly loses not only a part of its culture, but also of its very being. Can a historical series be therefore helpful in this extremely difficult task? It is appropriate to refer to the words of Sylwia

przeciwnika zabić czy wsadzić do więzienia, ale o to, by przekazywał Niemcom fałszywe informacje'. Pogranicze w ogniu, 'Antena' 29 August - 4 September 1992, p. 15.

14 'jest to, przedstawiona w konwencji sensacyjnej, historia zmagań Rzeczypospolitej z niemieckim ekspansjonizmem, widziana wycinkowo przez pryzmat walki wywiadów. Scenariusz oparty jest na autentycznych wydarzeniach dwudziestolecia, jednak nie jest to ani prosta rekonstrukcja spraw, ani para-dokument'. ODiZP, PJO, ref. 2149/30, vol. 22, Dokument pt. 'Serial telewizyjny Pogranicze w ogniu', p. 1.

15 Ibidem, p. 3.

16 ODiZP TVP, PJO, ref. No. 2149/30, vol. 55, no pagination, Pismo Jerzego Kowalskiego do towarzysza Mirosława Wojciechowskiego z 7 września 1985 r. It should be added that J. Kowalski also communicated to M. Wojciechowski that 'Recenzenci z MSW byli pod takim wrażeniem lektury, że powierzyli aktualnie p. J. Janczurowi (współautorowi scenariusza) pisanie serialu o pracy wywiadu PRL po wojnie, opłacając wszystkie prace literackie i udostępniając w tym celu archiwa MSW (tytuł roboczy 'Tajny labirynt')' ['The reviewers from the Ministry of the Interior were so impressed with their reading that they entrusted Mr. J. Janczur (co-scriptwriter) with the writing of a series on the intelligence work after the war, with all the literary work paid and the archives of the Ministry of the Interior made available for that purpose (working title 'The Secret Labyrinth')]. See: Ibidem.

17 'najważniejsze, żeby powstawały filmy historyczne, które budzą dyskusje. Bo wtedy historia żyje'. https://teleshow.wp.pl/pogranicze-w-ogniu-widzowie-ogladali-ten-serialnie-tylko-dla-pieknych-aktorek-6026635421340289g/7 [accessed on: 20 V 2019]. 
Chutnik: 'Using the film series formula and its rooting in pop culture is a continuation of the proposal to accustom and promote history' ${ }^{\prime 18}$. It is difficult to disagree with this opinion, especially in a situation when the Polish society, and definitely its youngest part, has undergone a cultural revolution which resulted in a shift from the typographic to the audiovisual, digital culture paradigm. What do we then expect from the past? 'Is it only a confirmation matching our theses ${ }^{19}$, asked S. Chutnik, 'which, even if they did not exist, could be invented in accordance with the principle of fitting facts to the thesis?' ${ }^{20}$. This principle will find uncompromising supporters, no doubt about it; however, a professional historian should answer otherwise. First of all, history should be presented in a righteous way (to what extent this postulate is realistic is a different matter), expecting (as far as possible) specific answers or suggestions related to questions important for the nation, state and society. This may be called politics of history, but it cannot be turned into a tool for using history for particularist interests of a political party or a specific group of people (e.g. the one in power at a given moment in time). Tomasz Merta said expressly that 'the politics of history of a democratic state must not ignore the notion of historical truth: it must remain strictly related to it. History cannot be falsified or cleared away of what is not beautiful, not pretty ${ }^{21}$.

The question of using politics of history is of lesser importance from the point of view of the analysis of the titular series ${ }^{22}$. After all, Borderline on Fire has neither become a cult series ${ }^{23}$ nor a particularly discussed one,

18 'Wykorzystywanie formuły serialu i jej zakorzenienie w popkulturze jest kontynuacją propozycji oswajania i promowania historii'. S. Chutnik, op. cit., p. 10.

19 'Czy tylko pasujących do naszych tez potwierdzen'.

20 'które choćby nie istniały, to da się je wymyślić zgodnie z zasadą dopasowywania faktów do tezy?'. S. Chutnik, op. cit., p. 13.

21 'polityka historyczna demokratycznego państwa nie może ignorować pojęcia prawdy historycznej, musi pozostawać w ścisłej z nią relacji. Nie można fałszować historii albo usuwać z niej rzeczy niepięknych, nieładnych'. As quoted in: S. Chutnik, op. cit., p. 14.

${ }^{22}$ About the dispute over the politics of history in the Third Republic of Poland: P. Machcewicz, Spory o historię 2000-2011, Kraków 2012, pp. 172-176, 182-187, 188-194.

${ }^{23}$ It is a relative notion whether something is a so-called cult production. However, sayings or dialogues from the series are clearly absent in the public space. This does not mean, however, that a few examples cannot be mentioned. They were probably not as successful - and thus they did not become popular - as those from Sexmission [Seksmisja] or 'More than Life at Stake', some of them are, nevertheless, worth quoting: Tadeusz Kaleta: 'Żołnierz żeby nie gnuśnieć, musi ćwiczyć' ['A soldier must exercise not to moulder'] (episode 3); Tadeusz Kaleta to Czarek Adamski about his doubts about the service: ‘Wywalczyliśmy tę Polskę. Budujemy ją... i będziemy jej bronić. Ze wszystkich sił. Do ostatka. Bo jaka jest, jest święta. Będziemy dla niej pracować i dla niej walczyć. Po żołniersku. Jak każdy potrafi... Tak to jest naprawdę ' ['We won that Poland by fighting. We're building her... and we'll defend her. With all strength. To the last. Because as she 
rarely, if ever, used in the current politics of history. We can even get the impression that the series went unnoticed in the period of its broadcast (1992-1993) ${ }^{24}$. While this carries a significant deal of generalization, it must be kept in mind that the premiere took place at a time when most Poles were preoccupied with either 'consuming' the new system or adapting to its requirements. It was not without significance that nobody was then pursuing a conscious politics of history in Poland ${ }^{25}$ and the Internet was more than a luxury good. The lack of widespread reception of Borderline on Fire was also due to the Polish Television's fault: the series, produced with an enormous effort and resources (about 1 billion of the then zloty) ${ }^{26}$, would be broadcast on Mondays at 11.05 p.m. ${ }^{27}$

is, she's sacred. We'll work for her and fight for her. Soldierly. Everyone doing their best... That's the way it really is'] (episode 24); Franz Relke to Czarek Adamski: 'Wiesz, na froncie nauczyłem się jednego: Befehl ist Befehl ('rozkaz to rozkaz')' ['You know, there was one thing I learned at the front: Befehl ist Befehl ('an order is an order')] (episode 2); Voraczek to Wetter on how to prepare the ground to force someone to cooperate as an agent: 'Widzisz, Wetter... Rozmowa z takim człowiekiem to jest corrida. Najpierw różni pomocnicy gonią byka po arenie. Drażnia, kłują. A dopiero wtedy, kiedy jest wykrwawiony, osłabiony, kiedy ledwo trzyma się na nogach, dopiero wtedy... wchodzi na arenę torreador i zadaje jeden, jedyny, śmiertelny cios... Właśnie tego mi brakuje. Żeby był bez oddechu, na kolanach. Żeby, kiedy podsuniesz mu pod nos ten tajny rozkaz, żeby miał tylko siłę jęknąć' ['You see, Wetter... Talking to such a man is a corrida. First, various helpers chase the bull around the arena. They irritate him, they prick him. And only when he's bled out, weakened, when he's barely on his feet, it's only then... that a bullfighter enters the arena and deals one, only one, deadly blow... That's what I need. Get him on his knees, breathless. So that when you put this secret order under his nose, he only has the strength to moan'] (episode 5). See: https://pl.wikiquote.org/wiki/Pogranicze_w_ogniu [accessed on: 20 V 2019].

${ }_{24}$ This does not mean, in the least, that no articles appeared in the press; those, however, were usually short and, rather than analysing the series in depth, they just announced it. Cf. inter alia: K. Głogowski, op. cit.; Pogranicze w ogniu; OPAL, Pogranicze w ogniu, 'Sztandar Młodych' 8 February 1993, p. 14; (M.W.), Koniec 'Pogranicza w ogniu', 'Antena', 6-12 February 1993, p. 2.

25 Tomasz Merta wrote that: 'polityka historyczna jest konieczna, a w pierwszym piętnastoleciu III Rzeczypospolitej w ogóle jej nie było [...]' ['politics of history is necessary, and it was non-existent in the first fifteen years of the Third Polish Republic [...]']. See: T. Merta, Pamięć i nadzieje, in: Pamięć i odpowiedzialność, eds. R. Kostro, T. Merta, KrakówWrocław 2005, p. 71; In the same work, Robert Kostro and Tomasz Merta also concluded that, in the beginning of the Third Republic of Poland, 'Nazbyt pospiesznie 'wybierając przyszłość' część elit politycznych i intelektualnych uznało, że polityka historyczna jest czystym anachronizmem, któremu nie warto poświęcać zbyt wiele czasu i energii' ['too hasty in 'choosing the future', some political and intellectual elites deemed politics of history was a pure anachronism, not worth devoting too much time and energy']. See: R. Kostro, T. Merta, Wstęp, in: Pamięć i odpowiedzialność, eds. R. Kostro, T. Merta, KrakówWrocław 2005, p. VII.

26 Detailed cost estimate: ODiZP TVP, PJO, ref. no. 2149/30, vol. 29.

27 Andrzej Konic expressed that in many press interviews. Cf. e.g. (M.W.), op. cit., p. 2; At the same time, he expressed the view that 'nie możemy spodziewać się niczego 
It was the spread of the Internet that made real-time discussions possible ${ }^{28}$. There is no doubt that the lack of this medium had a huge impact on their initial lack ${ }^{29}$. It should be noted, however, that the series was not broadcast too often, and if at all, it was on TV channels considered thematic or 'niche' from the statistical viewer's point of view. Not even all its episodes have been made available on the free YouTube channel to this day. This does not mean that this series did not have faithful and devoted viewers. We do not know what size of audience it gathered $^{30}$, but there is no doubt that its vast majority (at least judging by the number of posts on discussion forums) received the series well or very well ${ }^{31}$.

lepszego po telewizji publicystycznej, w której najważniejsza jest polityka, a nie telewizja' ['we can't expect anything better from journalistic television where it's politics, not television, that matters most']. See: OPAL, Pogranicze w ogniu, 'Sztandar Młodych' 8 February 1993, s. 14.

${ }^{28}$ Czesław Witkowski rightly noticed that history returned to public discourse in the late 20th and early 21st century. See: Cz. Witkowski, Majowy zamach stanu. Czy działania podjęte przez pitsudczyków byly w petni zaplanowane, czy też w dużym stopniu okazały się działem przypadku? Wojskowy rokosz Piłsudskiego, Warszawa 2016, p. 11.

${ }_{29}$ In a statement addressed to a right-wing reader in 2008, Tomasz Formicki affirmed that the content of the series clearly indicated the mechanisms and directions in German foreign policy (Drang nach Osten); moreover, since 1989 Poles had been told that Germany was our 'best advocate in foreign policy', which influenced such a late release of the series on DVD. In his opinion, these reasons could have prevented a broader public debate. Polonocentrism noticeable throughout the series was not to be neglected, either. See: T. Formicki, op. cit., p. 17.

30 In the pages of 'Sztandar Młodych', one of the editors argued that 'the series gained a constant and quite large audience', basing that assumption on OBOP public opinion survey. However, no numerical values have been provided there. See: OPAL, Pogranicze w ogniu, 'Sztandar Młodych' 11 January 1993, p. 14.

31 The discussion on the forum was initiated by user «Janowiak» who asked: 'Co sądzicie o tym serialu?' ['What do you think about this series?']. In response, «MikeR» stated that it was 'bardzo dobry serial, przede wszystkim ze względu na wątek patriotycznowielkopolski' ['a very good series, owing mainly to the patriotic and Greater-Poland theme']. See: http://www.dws.org.pl/viewtopic.php? $\mathrm{f}=97 \& \mathrm{t}=3416 \& \mathrm{st}=0 \& \mathrm{sk}=\mathrm{t} \& \mathrm{sd}=\mathrm{a}$ [accessed on: 21 V 2019]; In turn, «Tołdi», elaborating on their statement a bit more, concluded: 'No mój ulubiony - szczególnie, że jest sporo historycznych wątków oraz, że nie robią z jednej strony kompletnych oferm a z drugiej super-hiper czegoś - serial wyważony i naprawdę nieźle zrobiony - jak już wspomniałem MÓJ ULUBIONY' ['Well, my favourite - all the more that it has a lot of historical threads and, on the one hand they don't show folks as total wet rags but not as a super-duper thing either, on the other hand - the series is balanced and really well made - as I already mentioned MY FAVOURITE']. See: Ibidem; Another user («Strategos») wrote: 'też bardzo lubię ten serial. Zupełnie nieamerykańska szkoła podejścia do źródeł historycznych' ['I like this series very much too. A very non-American approach to historical sources']. See: http://www.dws.org.pl/viewtopic.php?f=97\&t=3416 [accessed on: 21 V 2019]. 
This undoubtedly testifies to the good level of the script ${ }^{32}$, directing, set design $^{33}$ and, perhaps most of all, acting ${ }^{34}$. However, some more reserved ${ }^{35}$

32 User «Ares» wrote: ‘Autorzy scenariusza zadali sobie wiele trudu żeby pokazać nam autentyczne postacie i autentyczne sytuacje, które kiedyś miały miejsce. Oprócz powszechnie znanych epizodów jak słynna akcja 'Wózek', czy też złamanie szyfru Enigmy i działalność rotmistrza Sosnowskiego wpletli oni w scenariusz inne historie ze zmagań na 'cichym' froncie pomiędzy rokiem 1918 a 1939' ['Authors of the script have taken many troubles to show us authentic characters and authentic situation that did happen in the past. In addition to the well-known episodes such as the famous operation 'Wózek', the breaking of the Enigma code, the activities of Rittmeister Sosnowski, they wove other stories from the struggle on the 'silent' front between 1918 and 1939 into the script']. See: http://www. dws.org.pl/viewtopic.php? $\mathrm{f}=97 \& \mathrm{t}=3416 \& \mathrm{st}=0 \& \mathrm{sk}=\mathrm{t} \& \mathrm{sd}=\mathrm{a} \&$ start $=50$ [accessed on: $21 \mathrm{~V} \mathrm{2019}$ ]; User «karolz77» assessed the series as follows: 'Bardzo dobry serial, myślę że w dużej mierze odpowiada prawdzie. Żeby całościowo zrozumieć jego fabułę trzeba mieć przynajmniej podstawową wiedzę o historii Polski przedwojennej i stosunków polsko-niemieckich, ale nawet kompletny laik również może strawić ten film ze względu na napiętą akcje i świetnie skonstruowane dialogi' ['A very good series, I think it largely corresponds to the truth. To understand its plot on the whole, one must have at least basic knowledge of the history of pre-war Poland and Polish-German relations, but even a complete muggle can also digest the film thanks to the fraught action and brilliantly structured dialogues']. See: http://www. historycy.org/historia/index.php/t66370.html [accessed on: 21 V 2019].

33 The set design, despite limited financial and technical possibilities, withstood criticism. During the discussion, attention was paid to the uniforms, selected by Jan Rutkiewicz and Kazimierczak. See: http://www.dws.org.pl/viewtopic.php?f=97\&t=3416\& st $=0 \& s k=t \& s d=a \& s t a r t=100$ [accessed on: 21 V 2019].

34 User «Janowiak» wrote on 8 March 2011: ‘[...] jeśli chodzi o aktorstwo - moim zdaniem nie było tutaj większych wpadek. Więcej - niektóre postacie, by wymienić chociażby Czarka Adamskiego, granego przez Cezarego Pazurę, Jacques'a Dalarona, w którego wcielił się Jacek Kałucki, przełożonego Dalarona - Bertranda, granego przez Witolda Skarucha, Sylwka Madeja granego przez Jana 'Tulipana' Monczkę, por. Daniela Czaprana, w którego postać wcielił się Marek Lewandowski czy w końcu Filipa Sarnę, granego przez Włodzimierza Adamskiego, to prawdziwe małe perełki. Może nie takie, jak chociażby Stępień z 13 posterunku grany przez Marka Walczewskiego (rola godna Oscara), ale warte odnotowania' ['when it comes to acting, there were no major mishaps, in my opinion. Moreover: some of the characters, such as Czarek Adamski, played by Cezary Pazura, Jacques Dalaron, played by Jacek Kałucki, Dalaron's superior Bertrand, played by Witold Skaruch, Sylwek Madej played by Jan ‘Tulipan’ Monczka, cf. Daniel Czapran, played by Marek Lewandowski and, not least, Filip Sarna, played by Włodzimierz Adamski, are real little gems. Maybe not comparable, for instance, to Stępień from 13 posterunek played by Marek Walczewski (a role deserving an Oscar), but worth mentioning']. See: http:// www.dws.org.pl/viewtopic.php? $\mathrm{f}=97 \& \mathrm{t}=3416 \& \mathrm{st}=0 \& \mathrm{sk}=\mathrm{t} \& \mathrm{sd}=\mathrm{a} \& \mathrm{start}=25$ [accessed on: 21 V 2019]. On the other hand, user «Messer» stated that 'grali aktorze, którzy zanim zostali aktorami, to mieli odbytą służbę wojskowa, choćby w Zegrzu, jak Cezary Pazura. A to przekłada się na granie 'roli mundurowej' [...]' ['actors from the cast had completed military service before becoming actors, for example in Zegrze, like Cezary Pazura. And that translates into playing a 'uniform part' [...]']. See: http://www.dws.org.pl/viewtopic. php?f=97\&t=3416\&st=0\&sk=t\&sd=a [accessed on: $21 \mathrm{~V} 2019]$.

35 User «alcesalces1» wrote on 16 March 2010: ‘[...] serial kiedyś bardzo mi się podobał... ale teraz odnoszę wrażenie, że się jednak 'nie sprzedał'. [...] Interesujące jest 
and critical opinions should be noted aswell ${ }^{36}$. A question should be asked whether they correspond to the actual state. Did the series really deserve such high ratings or critical words? I will elaborate on this further on in the text.

Before moving on to a detailed analysis, it is necessary to present general statements and ask some questions about the film series as a form of communication. First of all, how should the series be understood and perceived in a cultural context ${ }^{37}$, how should it be positioned in relation to historiography, how does argumentation and public debate on this topic develop and what are its most important aspects? The latter issue deserves a few remarks, as the question of how to reflect on series remains still

to, choć w sumie nie dziwi, że w serialu całkowicie pominięty jest wątek sowiecki, nie wspomina się go, ani w sensie pozytywnym, ani negatywnym. Są oczywiście wątki przesiąknięte pewną melodramą i ckliwościa, ale nie $\mathrm{w}$ mniejszym stopniu niż Czas honoru. Chyba to jest nieodłączny ciężar takich produkcji, by nie wyglądały jak sztywne rekonstrukcje z programów Wołoszańskiego' ['I used to like the series a lot ... but now I have the impression that it 'didn't sell' . [...] What is interesting - although not surprising, after all - is the complete omission of the Soviet motif in the series, without mentioning it in a positive or negative sense. Obviously, there are threads permeated with certain melodrama and soppiness, but to an extent no lesser than Time of Honour. I guess this is the inherent burden of such productions, otherwise they look like rigid reconstructions from Wołoszański's programs']. See: http://www.historycy.org/historia/index.php/t66370. html [accessed on: 22 V 2019]. User «Baszybuzuk», in a polemic with other users about Borderline on Fire said: 'Zestarzało się to-to potwornie, a aktorzy są zmanierowani nie gorzej niż obecni. Poziom wykonania tak coś w stylu Przyłbic i kapturów. Temat jest fajny, ale realizacja bardzo, bardzo oszczędna' ['It's gotten horribly old, and the actors are no worse than the present ones. The level of performance is something like Przytbice i kaptury. The subject is cool, but the production is very, very scrimpy']. See: http://www.historycy. org/historia/index.php/t66370.html] [accessed on: 22 V 2019].

36 User «tabaryta» considered the series 'kolejną zmarnowaną okazję' ['another wasted opportunity'], calling the acting (with exceptions) 'polską 'typówką" ('Polish 'typical stuff'). See: $h t t p: / / w w w . d w s . o r g . p l / v i e w t o p i c . p h p ? f=97 \& t=3416 \& s t=0 \& s k=t \& s d=a ;$ [accessed on: 22 V 2019]. «Janowiak» replied to him: ‘Daj nam Boże teraz taką 'typówkę" [‘Dear God, give us such 'typical stuff' now']. See: http://www.dws.org.pl/viewtopic.php?f=97\&t=341 6\&st=0\&sk=t\&sd=a\&start $=25$ [accessed on: 22 V 2019]. On the other hand, the same user stated that 'od czasu, gdy naprawdę doceniłem ten serial (obecnie czasami zastanawiam się, czy nie nazwać go 'niedocenionym arcydziełem'), aż chce mi się go oglądać, jeżeli mam taką możliwość' ['since I really appreciated this series (today. I sometimes wonder if I should call it an 'underrated masterpiece'), I feel like watching it whenever I have the opportunity']. See: http://www.dws.org.pl/viewtopic.php?f=97\&t=3416\&st=0\&sk=t\&sd=a \&start $=75$ [accessed on: 22 V 2019].

37 According to Anna Krawczyk-Łaskarzewska, 'Seriale w kontekście kulturowym to antologia tekstów poświęconych mniej lub bardziej popularnym serialom fabularnych [...]' ['Film series in a cultural context is an anthology of texts devoted to more or less popular fiction series [...]']. See: A. Krawczyk-Łaskarzewska, O telewizji i dyskursie telewizyjnym - historia, fikcje, rzeczywistość, in: Seriale w kontekście kulturowym. Historia i polityka, eds. M. Cichmińska, A. Naruszewicz-Duchlińska, Olsztyn 2014, p. i. 
valid $^{38}$. According to Anna Krawczyk-Łaskarzewska, the parameters of the serial discourse should be modified, in order to seriously consider the suggestions of Anna Nacher postulating 'returnin to the analysis of the genre [i.e. the TV series - author's note] as a discursive formation [and to conduct - author's note] careful observation of how cultural experience is realized within it' ${ }^{39}$. This postulate seems justified, especially in the context of the reviewers' abuse of categorical hyperbole which often turn out to be of little use. In addition, we willingly and somewhat hastily mark out boundaries / breakthroughs while we just as eagerly 'omit or depreciate the achievements of series from the somewhat 'mysterious' and probably 'rightly bygone' pre-web era' ${ }^{\prime 0}$.

Thus, is Borderline on Fire - the script of which was written in the first half of the 1980s, with its first ten episodes produced (shot and edited) in 1987-1988 in the 'Perspektywa' Film Group ${ }^{41}$, and the first run taking place only in the early $1990 \mathrm{~s}^{42}$ - a series from the bygone era? ${ }^{43}$ At this point,

38 An example of a broader and more in-depth discussion is the series Czas honoru. See: Najpierw, pp. 26-27; S. Chutnik, op. cit., pp. 7-17.

39 'powrót do analizy gatunku [tj. serialu telewizyjnego - M.S.] jako formacji dyskursywnej [oraz przeprowadzić - M.S.] baczną obserwację, jak w obrębie realizuje się doświadczenie kulturowe'. As quoted in: A. Krawczyk-Łaskarzewska, op. cit., p. iv.

40 'pomijamy lub deprecjonujemy osiągnięcia seriali z nieco 'tajemniczej' i zapewne 'słusznie minionej' epoki przed Internetem'. Ibidem, p. ii.

41 The series was approved on 27-29 June 1988. ODiZP TVP, PJO, ref. no. 2149/30, vol. 55, no pagination, Pismo Przedsiębiorstwa Realizacji Filmów 'Zespoły Filmowe' Zespół Filmowy 'Perspektywa' do Naczelnej Redakcji Telewizyjnych Filmów Fabularnych z 27 IV 1988 r. The 'Perspektywa' Film Group was founded in 1978. Until 2011, it was managed by Janusz Morgenstern. The group (and then the studio) made over 100 productions, mainly fiction films, but also TV series. The production profile was very broad: from original cinema, through adaptations of literary works, costume films, to comedies and other genre films. On 9 November 2011, by the decision of the Minister of Culture, the Studio was merged with the 'Zebra' Film Studio. See: A. Wróblewska, Studio Filmowe (dawniej Zespót Filmowy) 'Perspektywa', in: http://www.akademiapolskiegofilmu.pl/pl/historia-polskiegofilmu/studia-filmowe/studio-filmowe-dawniej-zespol-filmowy-perspektywa/6 [accessed on: 23 V 2019].

42 It is worth adding that the fourteen subsequent episodes were not written until 1991. The series was broadcast on TVP from 31 August 1992 to 8 February 1993. https://teleshow. wp.pl/pogranicze-w-ogniu-widzowie-ogladali-ten-serial-nie-tylko-dla-pieknych-aktorek6026635421340289g/2 [accessed on: 23 V 2019].

43 According to user «Baszybuzuk», in technical terms, the series '[...] potwornie się zestarzał - takie filmowanie w stylu lat 70-tych/80-tych [XX wieku - M.S.] z długimi statycznymi ujęciami, w których siedzi sobie Czarek [Adamski - M.S.] w gabinecie i gada (i ta jego maniera $z$ tym 'tak...' wplatanym w każde zdanie), a posłuszny widz musi tego słuchać, czekając aż w końcu coś się stanie (to coś to zwykle ponętna agentka Abwehry czy knujący jakieś świństwa Franek/Franc [Relke - M.S.]). Widać, że realizatorzy mieli wielki ubaw ubierając aktorów w stroje z epoki, odtwarzając klimat przedwojennych knajp, bohemy i śmietanki towarzyskiej, ale wszystko to jest takie mocno kryzysowe...' 
two important aspects regarding the study of series are worth pointing out. The first one concerns the medium through which it is transmitted. The most important medium for mass audience in Poland in 2019, in my opinion, remains... television ${ }^{44}$. Of course, it is impossible to overlook the constantly growing role of the Internet or VoD platforms (Netflix, HBO, Showmax, etc.) in some age groups, but television still holds the lead in the mass transmission of facts and entertainment.

The second one follows from the first one, because if we assume that television is a carrier of convergence of traditional and modern media, then film series (without dividing them into specific types) present narratives that 'constitute a repertoire of biographical scripts through which we tell ourselves our own lives' ${ }^{45}$. This is how Anna Nacher put it, making a generalization in relation to TV series. Do her conclusions apply to Borderline on Fire?

A very large number of studies have been devoted to the history of the Second Republic of Poland. Thousands of monographs, articles and, above all, editions of sources, all undeniably confirm the thesis of historians' enormous interest in that period of Polish history. There is no sense in recalling even selected items, as they do not relate to the subject in any way. This peculiar paradox is explained by the fact that the authors did not mention the title series in any of those items. It is not difficult to explain it, as this production has not been the subject of scientific analysis so far, not having been recognized by historians, media scholars or cultural experts. The present study is, therefore, the first (considering

['[...] has grown terribly old - such filming in the 1970s/1980s style with long static shots showing Czarek [Adamski - author's note] sitting in his office and talking (that manner of dropping an 'ain't it?' into every sentence!), and the obedient viewer has to listen to it, waiting for something to happen ('something' being usually an alluring female Abwehr agent or Franek/Franz [Relke - author's note] scheming some dirty trick). You can see that the production team had a lot of fun dressing the actors up in historical costumes, recreating the atmosphere of pre-war pubs, bohemian and social crème, but all this is very recessionary...']. See: http://www.historycy.org/historia/index.php/t66370.html [accessed on: 23 V 2019].

44 A different view on this question was presented in 2011 by Anna Nacher, stating that ‘...] uległy wszystkie niemal jego [tj. serialu - M.S.] podstawowe parametry tekstualne - dzisiaj serialu nie doświadczamy ani jako szeregu epizodów, ani też nie oglądamy go $\mathrm{w}$ telewizji' ['[...] almost all of its [i.e. the series' - author's note] basic textual parameters have changed; today, we do not experience the series as a sequence of episodes, nor do we watch it on television']. See: A. Nacher, Serial 2.0 - model do składania, in: Post-soap. Nowa generacja seriali telewizyjnych a polska widownia, eds. M. Filiciak, B. Giza, Warszawa 2011, p. 234. It should be noted, however, that this analysis is general in nature. Thus, we do not know if there is a statistical difference between Poland and Western countries and the USA.

45 'stanowią repertuar biograficznych skryptów, za pomocą których opowiadamy sobie własne życie'. A. Nacher, op. cit., p. 226. 
also Internet resources) comprehensive attempt to analyze the series in terms of the message about the interwar period. We should mention here, however, Tomasz Formicki's journalistic article ${ }^{46}$ written on the occasion of the publication of the series on DVD in 2008.

What should be considered in the first place is the genesis and motives of producing such a series. The first half of the 1980s was a time of martial law and, simultaneously, of a huge political and economic crisis. Janusz Janczur's reasons for writing a script of the first five episodes remain unknown in that context ${ }^{47}$. We can only guess that the topic was taken up out of fascination with the history of the interwar period, longing for a sovereign, free and 'normal' state (the Second Polish Republic being perceived as one, at least from the perspective of the series). Initially, J. Janczur was working on his own but, after critical reviews of Krzysztof Teodor Toeplitz $^{48}$, Prof. Jerzy Bossak and Zbigniew Safin, he accepted the help of Andrzej Konic, director of such series as More Than Life at Stake [Stawka większa niż życie] and Black Clouds ${ }^{49}$ [Czarne chmury]. It was a breakthrough moment, the reviews that followed were much milder in their form ${ }^{50}$

${ }^{46}$ T. Formicki, op. cit., pp. 16-17.
47 I have not found any documents relating to Borderline on Fire in the archival group
of the Supreme Cinematography Board [Naczelny Zarzad Kinematografii]. However,
the memo of 29 July 1983, prepared after consultations with the management of the Film
Groups, is worth paying closer attention. Its analysis shows that motifs related to the Second
Polish Republic (Kanonierka; Vabank II), albeit present in Polish cinematography, would still
arouse controversy. See: Archiwum Akt Nowych, Naczelny Zarząd Kinematografii, ref. no. $5 / 45$, sheets $28-35$.

48 The reviewer criticised the script of the first episodes for their 'nadmierne rezonerstwo i zbyt małyu element atrakcyjności w rozumieniu filmu sensacyjnego' ['overexplaining and insufficient element of attractiveness in the meaning of an action film']. See: ODiZP, PJO, ref. no. 2149/30, vol. 27, no pagination, Overall opinion.

49 In the document summarising the reviews of the first episodes, its author (illegible signature) stated: 'Po tych wszystkich uwagach, z których wiele zgodnych było z opiniami redakcji, doprowadziliśmy do szeregu spotkań z autorem [J. Janczurem - M.S.]. Odbyły się wielogodzinne dyskusje i narady. Zasugerowaliśmy autorowi dokooptowanie reżysera serialu, jako współscenarzysty, co p. Juliusz Janczur przyjął' ['After all these remarks, many of which were consistent with the editors' opinions, we had a series of meetings with the author [J. Janczur - author's note]. Hours of discussions and deliberations took place. We suggested the author co-opted the director of the series as a co-scriptwriter, which Mr. Juliusz Janczur accepted']. See: Ibidem.

${ }^{50}$ In the document comprehensively presenting the historians' reviews (M. Wojciechowski, Col. Kozłowski), officers of the General Staff (Col. M. Moraczewski), the Main Political Board of the Polish Armed Forces (Col. M. Jurek) and the Ministry of the Interior (Col. E. Podpora, Ph.D. and Col. A. Maj) stated that 'Wszyscy recenzenci wyrażają się pochlebnie o serialu, zgodnie podkreślając jego wartości ideowe, polityczne i historyczno-poznawcze' ['All reviewers express flattering opinions about the series, unanimously emphasising its ideological, political and historical-cognitive values']. See: ODiZP TVP, 
and the series itself gained recognition of decision makers including Zygmunt Wiśniewski, head of the Film Production Department [Dział Produkcji Filmów] who stated, on 15 February 1984: '[scripts of episodes] I-VIII. I have read the whole work and find it to be well-elaborated" ${ }^{51}$. At the same time, the series was considered 'politically important' and in-

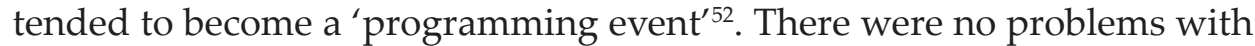
censorship $^{53}$, or at least nothing is known about it. The reason could be the main motif: the intelligence game, an inherent feature of all political systems. Moreover, in this particular case, a Pole and a German were placed opposite each other, which was not without significance in the political situation of the time, giving even a symbolic meaning to the confrontation. The question was to what extent were the creators supposed to rely on facts and to what extent vent their fantasy $?^{54}$. The characters of both rivaling friends from youth (Cezary and Franciszek) are poetic license, but the background of the struggle is based on facts. The plot is based on the rivalry between a Pole and a German (good versus evil) shown against the background of a contest of two military intelligence services (The Second Department of Polish General Staff and the Abwehr ${ }^{55}$. In this way, the screenwriters largely avoided strictly political motives which would have unavoidably aroused controversy among reviewers, especially those from the Main Political Board of the Polish Army and the Ministry of the

PJO, ref. no. 2149/30, vol. 22, no pagination, Dokument pt. 'Serial telewizyjny Pogranicze wogniu', p. [3].

51 '[scenariusze odcinków] I-VIII. Czytałem całość i uważam za dopracowaną' ODiZP TVP, PJO, ref. no. 2149/30, vol. 22, no pagination, Metryka scenariusza serialu Pogranicze, odcinki XI-XIV.

52 Ibidem, no pagination, Metryka scenariusza Pogranicze do odcinków XV-XX, 28 August 1984.

53 On film censorship in 1977-1989, see: A. Misiak, Kinematograf kontrolowany. Cenzura filmowa w kraju socjalistycznym i demokratycznym (PRL i USA). Analiza socjologiczna, Kraków 2006, pp. 301-305, 316-319.

${ }^{54}$ In August 1987, A. Konic stated that ‘Większość serialu jest napisana na podstawie materiałów historycznych. Gdyby wszystko było takie łatwe nie istniałyby wywiady i kontrwywiady. Nie byłoby też ciekawej fabuły naszego serialu' ['Most of the series is written on the basis of historical materials. If everything were easy, there would be no espionage or counterespionage. There would be no interesting plot for our series, either']. See: M. Mokrzycka, 'Pogranicze w ogniu' w Warszawie, 'Express Wieczorny' 26 August 1987, p. [10].

${ }_{55}$ On the other hand, the director emphasised in one of the interviews that his intention 'nie było ukazanie Niemców źle, jako ludzi, lecz oddanie walki politycznej. Motorem akcji jest pojedynek myśli i idei, z czego dopiero wynika intryga' ['was not to portray the Germans in a bad light as people, but to reflect political struggle. The driving force behind the action is a duel of thoughts and ideas, and the plot only stems from it']. See: (M.W.), op. cit., s. 2. 
Interior. The Germans could undoubtedly be shown from the evil side, but how to show the pre-war non-Communist politicians in a good light?

Giving up politics as the main narrative theme worked out well for the series. The ubiquitous theme of the army, which could be positively associated by viewers due to the ethos of combat, heroism, and sacrifice, did not pose major threats from censorship. After all, the army (even in People's Poland) was an armed force appreciated and respected by the society, and although it had dirtied itself with participation in suppressing workers' riots more than once, soldiers were received much better than... members of such formation as the Militia, Security Services or the ZOMO. Soldiers could always be relied upon (the army would help in case of natural disasters); moreover, there was a still binding tradition of the 'very best boys'.

A detailed analysis of the plot of the twenty-four episodes of Borderline on Fire would defeat the purpose. However, for better understanding of the concept of the series, it is impossible to leave the main plot unspecified. Before that, however, it is worth mentioning the title itself, which, in my opinion, perfectly reflects the spirit of the series. Borderline is an ambiguous and, therefore, vague term. In this way, it forces the recipient to specify the place(s) where the action takes place, or the period (time) in which two cultures and epochs border with each other. The lack of caesuras only emphasizes the vagueness. The second part of the title is, conversely, clearcut (in combination with the first one): in this case, fire symbolizes flames, shooting, and therefore an armed conflict which always leads to casualties.

The plot is a creative vision of history based on historical patterns ${ }^{56}$. The series' narrative arc, conducted - nota bene - only in Polish ${ }^{57}$, begins in the capital of the Greater Poland region, the cradle of the Polish state, where the authors of the script placed the two main characters: Czarek Adamski (played by Cezary Pazura) and Franciszek/Franz Relke (played

56 Krzysztof Głogowski stated that the series 'ma pokazać walkę pomiędzy polskim i niemieckim wywiadem od I do II wojny światowej. Jego realizatorzy wspomagają własną fantazję konkretnymi zdarzeniami i życiorysami' ['is intended to show the struggle between Polish and German intelligence from the World War I to the World War II. Its producers support their own fantasy with specific events and biographies']. See: K. Głogowski, op. cit., p. 2; Models of the characters are commented on in detail by user «Ares». See: http:// www.dws.org.pl/viewtopic.php? $\mathrm{f}=97 \& \mathrm{t}=3416 \& \mathrm{st}=0 \& \mathrm{sk}=\mathrm{t} \& \mathrm{sd}=\mathrm{a} \&$ start $=50$ [accessed $\mathrm{on}$ : 3 VI 2019].

57 User «QUOTE» rightly noticed that the series would gain realism if the dialogues were not all in Polish. He argued that 'W końcu język niemiecki, tym bardziej kaszubski czy gwara śląska nie są w naszej części Europy niczym egzotycznym...' ['The German language, and the Kashubian or Silesian dialect all the more, are nothing exotic in our part of Europe after all...']. See: http://www.historycy.org/historia/index.php/t66370.html [accessed on: 3 VI 2019]. 
by Olaf Lubaszenko) ${ }^{58}$. They are colleagues (Poles, by implication), whose paths split quite early as a result of a highly probable situation ${ }^{59}$. Recent friends stand on opposite sides of the barricade, understood both literally and figuratively. The reason is the story of a German father who dies on the Western Front during World War I. Polish deserters from the imperial army reportedly contributed to the tragedy. The situation is all the more tragic that Franek/Franz's mother is Polish.

The Greater Poland Uprising, in which both heroes fight, is the time of forging their intelligence talents, which was shown in episode 4 . In the following one, we observe the fates of Czarek and Franz become more and more closely related to military intelligence services ${ }^{60}$. There are also new, significant characters: Major Tadeusz Kaleta, Bernard Graba, Rittmeister Jerzy Osnowski, Ewa Wicherek, Hans Voraczek, Mamel.

The narrative is chronological, but not year after year. The authors of the script chose, however, key moments from the common Polish-German history $(1918-1919,1928,1932,1934,1939)$ and the following issues: the Greater Poland Uprising, the scandal of Rittmeister Jerzy Sosnowski (the action codenamed In. 3) ${ }^{61}$, Operation 'Wózek' ${ }^{62}$, Hitler's rise to power,

58 The cast included also Katarzyna Chrzanowska, Barbara Sołtysik, Maria Gładkowska, and Ewa Sarówka. See: https://teleshow.wp.pl/pogranicze-w-ogniu-widzowie-ogladaliten-serial-nie-tylko-dla-pieknych-aktorek-6026635421340289g/2 [accessed on: 3 VI 2019].

59 This thread was characterised in an interesting way on an internet portal: ‘Hamletowski klimat. Dwóch przyjaciół: jeden przechodzi na złą stronę, oczywiście z naszego punktu widzenia. Ale zdradza, więc z każdego punktu widzenia jednak Olaf Lubaszenko to zły człowiek do szpiku kości. Zdradza przyjaciół, zabija dziewczynę swojego przyjaciela i potem jeszcze mu mąci. Natomiast Cezary Pazura jest kryształowy od początku do samego końca - opisywał głównych bohaterów Wojciech Krzyżaniak' ['A Hamlet-like atmosphere. Two friends: one passes to the evil side, of course from our point of view. But he's a traitor, Olaf Lubaszenko is a man bad to the bone, no matter what point of view we take. He betrays his friends, kills his friend's girlfriend and then lies to him. Cezary Pazura, conversely, is crystal-clear from the beginning to the very end - described the main characters by Wojciech Krzyżaniak']. See: https://teleshow.wp.pl/pogranicze-wogniu-widzowie-ogladali-ten-serial-nie-tylko-dla-pieknych-aktorek-6026635421340289g/2 [accessed on: 3 VI 2019].

${ }^{60}$ Tomasz Formicki pointed out a detail concerning Czarek Adamski's consent to work in 'Dwójka', stating that 'Adamski daje się przekonać do pracy w wywiadzie dopiero wtedy, gdy [Tadeusz] Kaleta informuje go, że w szeregach Abwehry na odcinku przeciwpolskim działa Relke' ['Adamski does not get brought around to work in intelligence service until [Tadeusz] Kaleta informs him of Relke's activity in the anti-Polish section of the Abwehr']. See: T. Formicki, op. cit., p. 16.

61 See: H. Ćwięk, W tajnej stużbie II Rzeczypospolitej. Wywiad Polski wobec Niemiec w latach 1918-1939, Częstochowa 2009, pp. 189-219.

62 The operation was organised by Major Jan Żychoń and aimed at intercepting confidential German mail transported by Berlin - East Prussia trains (in Poland, on the Chojnice - Tczew section). See: H. Ćwięk, op. cit., pp. 227-229. 
and the breaking of the 'Enigma' code. The series ends with the nostalgic episode twenty-four, set in 1939, on the eve of the war. It is as symbolic as the first one as it brings Franz Relke, twenty years later, back to his mother, who had remained faithful to her Polish nationality for two decades. The meeting of both takes place in Poznan, which is also symbolic (the beginning and the end in the same place). A 'moment' later, the GermanPolish war broke out ${ }^{63}$.

Regardless of how the series is judged, it should be repeated here that it was received well by critics as well as debaters on internet forums devoted to history ${ }^{64}$. I subscribe to such assessment for several reasons. First of all, it is a series ruled by intelligence and creativity. The heroes do not perform spectacular acts of courage, they do not show off their heroism, but they do not perish in glory either. It is a film about the superiority of the Polish 'Dwójka' [Second Department] over the German Abwehr. One may ask here why the co-writers and the director constructed the narrative precisely in that way. The answer - a partial one at least - comes from T. Formicki who stated that A. Konic had created a picture 'produced with the lowest expenditure possible... ${ }^{65}$. Undoubtedly, in the 1980s, budget insufficient for the scale and needs of the series was something to reckon with ${ }^{66}$; it should also be noted, however, that the level of special effects was very limited in Poland at that time, not only in comparison to the

${ }^{63}$ http://www.telemagazyn.pl/serial/pogranicze-w-ogniu-552417/odcinki/ [accessed on: 5 VI 2019].

64 An example of such assessment is user «Ares»'s post of 1 February 2010; he stated, inter alia, that the series, despite being 'już ponad dwadzieścia lat cały czas cieszy się sporą popularnością wśród miłośników historii i nie tylko' ['more than twenty years old already, is still very popular among history lovers and not only']. In his opinion, despite the shortcomings (boring action and not very fast dialogues), Borderline on Fire aroused interest and discussion, as the series showed 'kawał prawdziwej historii z działania naszego wywiadu i kontrwywiadu w okresie międzywojennym' ['a piece of true history from the operation of our intelligence and counterintelligence in the interwar period']. See: http://www.dws.org.pl/viewtopic.php? $\mathrm{f}=97 \& \mathrm{t}=3416 \& \mathrm{st}=0 \& \mathrm{sk}=\mathrm{t} \& \mathrm{sd}=\mathrm{a} \& \mathrm{start}=50$ [accessed on: 5 VI 2019].

65 'nakręcony maksymalnie niskim nakładem środków finansowych...'. T. Formicki, op. cit., p. 16.

${ }_{66}$ The production budget, planned in the mid-1980s, was to amount to 800 million zlotys at the time. Ultimately, the costs exceeded 1 billion zlotys. The sum seems impressive, but it is difficult to recalculate it into the contemporary amount. Moreover, as early as 1984, Zygmunt Wiśniewski, head of the Film Production Department, anticipated that 'dalsze prace będą dotyczyły zabiegów prowadzących do zmniejszenia kosztów produkcji' ['further work will be connected with steps leading to a reduction in production costs']. See: ODiZP TVP, PJO, ref. no. 2149/30, vol. 22, no pagination, Metryka scenariusza serialu Pogranicze, odcinki XI-XIV. 
current state ${ }^{67}$, (cf. the silhouette of the destroyer 'Wicher' on the road of the Gdańsk port).

The only option left was then to focus on such events that could be produced with available financial resources, while testifying to the Poles' intellectual and organizational potential and capabilities. Moreover, the script matched well the political narrative of the time (contemporary politics of history). This is, inter alia, the reason why Czarek Adamski's character is dynamic and full of life. He is a Polish patriot. His alter ego, Franz Relke, is calm and steady. Poles are also more successful and their achievements are shown more clearly in the series ${ }^{68}$. This is no surprise, as all cinematographies in the world do so. After all, it is normal and natural

${ }^{67}$ As it can be read on one of the contemporary web portals: 'Dzisiaj wielu entuzjastów Pogranicza w ogniu podziwia sposób, w jaki nakręcono poszczególne sceny produkcji. Trzeba bowiem wziąć pod uwagę niewielki budżet, jaki mieli do dyspozycji twórcy serialu. Musieli wybierać pomiędzy doskonałą jakością dźwięku czy obrazu, a samą opowieścią. Zdecydowali się na to drugie, co później okazało się słuszną decyzją. - To jest serial, który był robiony techniką filmową' ['Today, many enthusiasts of Borderline on Fire admire the way in which different scenes of the production were shot. What must be kept in mind is the small budget that the creators of the series had at their disposal. They had to choose between excellent sound or picture quality and the story itself. They opted for the latter, which proved to be the right decision. - This is a series made using the film technique']. See: https://teleshow.wp.pl/pogranicze-w-ogniu-widzowie-ogladali-tenserial-nie-tylko-dla-pieknych-aktorek-6026635421340289g/4 [accessed on: 5 VI 2019]; The low budget was also pointed out by user «AlexG», judging 'the means of expression'. See: http://www.dws.org.pl/viewtopic.php? $\mathrm{f}=97 \& \mathrm{t}=3416 \& \mathrm{st}=0 \& \mathrm{sk}=\mathrm{t} \& \mathrm{sd}=\mathrm{a}$ [accessed on: $5 \mathrm{VI}$ 2019]; User «Modeno» pointed out the shortcomings of the series. Those included the lack of sound normalisation, as a result of which some dialogues are hard to hear, while others are too loud. He considered special effects to be 'low-grade'. See. http://www.dws.org.pl/ viewtopic.php? $\mathrm{f}=97 \& \mathrm{t}=3416 \& \mathrm{st}=0 \& \mathrm{sk}=\mathrm{t} \& \mathrm{sd}=\mathrm{a} \& \mathrm{star}=100$ [accessed on: 5 VI 2019].

${ }^{68}$ It should be noted that the topic of the promotions of both main characters provoked a discussion. It was precisely the expressiveness of both promotions that gave rise to an exchange of views. User «Janowiak» concluded it as follows: 'W przypadku awansu na kapitana [Czarka Adamskiego - M.S.] - o ile mnie pamięć nie myli - zgoda, ten awans nie jest tak wyraźnie zaznaczony jak awans Franka [Relke - M.S.]. Awans na porucznika zaznaczony jest jednak bardzo wyraźnie - patrz początek odcinka 12, gdzie między innymi można usłyszeć takie słowa kierowane przez Czarka [Adamskiego - M.S.] [do] por. Daniela Czaprana: 'Z gwiazdkami tak jak z dziewczynami - zawsze dwie niż jedna. Mało tego - awans Czarka [Adamskiego - M.S.] na porucznika jest chyba najbardziej wyraźnie zaznaczonym awansem w całym serialu' ['In the case of promotion to captain [Czarek Adamski - author's note] - if I remember correctly - it is not marked as clearly as the promotion of Franek [Relke - author's note]. However, the promotion to lieutenant is distinguished very clearly - see the beginning of episode 12, where, among other things, you can hear such words of Czarek [Adamski - author's note] addressed [to] Lt. Daniel Czapran: 'Stars are like girls: two always better than one. Not only that: the promotion of Czarek [Adamski - author's note] to lieutenant is probably the most highlighted one in the entire series"']. See: $h t t p: / / w w w . d w s . o r g . p l / v i e w t o p i c . p h p ? f=97 \& t=3416 \& s t=0 \& s k=t \& s d=a$ \&start=75 [accessed on: 7 VI 2019]. 
to appreciate one's own people at the cost of strangers. It should be noted, however, that the image of the German (the main hero) and his countrymen presented in Borderline on Fire is no longer the same as e.g. in A. Konic's previous series, More than Life at Stake. After all, it takes intelligent people of a certain level to play the game of intelligence services; that forced a convention different from the stereotypical one. Tomasz Formicki, analyzing the series at the time of its release on DVD, wrote in his text, addressed to readers with right-wing views, that it was based on facts (mentioned above), but also that 'the series shows the struggle in the field of acquiring and protecting modern technologies and scientific thought [Professor Rajmund Wolta's action in Jena - author's note], penetration of Polish institutions by German agentry operating under the cover of the German minority circles and organisations. The forms of the Abwehr's activities were shown very well and clearly; one example can be the concealment of the Abwehr outpost (Nebenstelle Danzig) in the Gdańsk police station, which operated under such cover in the anti-Polish sector ${ }^{\prime 69}$.

The series is imbued with geopolitics and geostrategy. The viewer can follow 'secret meetings of the highest state officers and decisions made by them in London, Paris and Warsaw' ${ }^{\prime 70}$. At the same time, it is not free from political nuances. One of them can be found in the moment of the decision to 'recruit' Rittmeister Osowski (actual name Jerzy Sosnowski), when C. Adamski reacts to the objections of his colleagues who say that, in May 1926, Osowski had not supported Józef Piłsudski. He states: 'He went to the relief of the legal government!'71, to which Lieutenant Daniel Czapran responded adamantly: 'These are the previous era's criteria. We have new ones now. You have to adapt to them and I advise you to do so too' ${ }^{72}$. An attentive viewer will find more 'flavors' of this kind. There seems to be no good reason for listing them, as it is impossible to quote them all. The

69 'w serialu pokazano walkę w sferze pozyskiwania i ochrony nowoczesnych technologii oraz myśli naukowej [akcja profesora Rajmunda Wolty w Jenie - M.S.], penetrację polskich instytucji przez niemiecką agenturę działającą pod przykrywką środowisk i organizacji mniejszości niemieckiej. Bardzo dobrze i przejrzyście ukazano formy działania Abwehry, jak chociażby ukrycie placówki Abwehry (Nebenstelle Danzig) w budynku policji gdańskiej, która pod tą przykrywką działał na odcinku przeciwpolskim'. T. Formicki, op. cit., p. 16.

70 'tajne narady najwyższych czynników państwowych i decyzje podejmowane przez nie w Londynie, Paryżu i Warszawie'. Ibidem; The scenes taking place in those cities were shot in Czechoslovakia, which resulted from the political situation of the time but, above all, from the lack of resources for shooting in Western Europe.

71 'Ruszył z odsieczą legalnemu rządowi!'.

72 'To są kryteria z poprzedniej epoki. Teraz są nowe. Trzeba się do nich dostosować i tobie też to radzę zrobić'. As quoted in: T. Formicki, op. cit., p. 16. 
above fragment draws the reader's attention to the dialogues and acting ${ }^{73}$. With regard to the latter question, I share T. Formicki's opinion that, for both main characters, we are dealing with blockbuster roles ${ }^{74}$. 'Everyone, the actors and the creators alike - as one of the Internet portals wrote focused on their work. Each of them wanted the production to meet the conditions of a war and spy film instead of becoming another pastiche of the genre ${ }^{75}$. The end result seems so satisfying that some viewers, especially those for whom the series is 'an extraordinary journey into the more and more forgotten past ${ }^{\prime 76}$, consider it 'almost a cinematic masterpiece ${ }^{\prime 77}$.

The presented picture would be incomplete without considering the opinions of those who decided to take part in a public discussion via internet forums. It should be noted that it started in 2004, to continue with interruptions - to this day. The analysis of the two main portals (dws

73 Years later, Cezary Pazura expressed the same opinion, stating that 'Pogranicze $w$ ogniu jest świetnie zrobionym filmem i to pod każdym względem: historycznym, jest dobrze zagrany, świetnie jesteśmy ubrani, wszystko w każdym szczególe się zgadza, jeśli chodzi o samochody czy rekwizyty' ['Borderline on Fire was a film well made in every respect: historical, well played, we're dressed up excellently, everything is correct to the smallest detail when it comes to cars or props']. https://teleshow.wp.pl/pogranicze-wogniu-widzowie-ogladali-ten-serial-nie-tylko-dla-pieknych-aktorek-6026635421340289g/6 [accessed on: 11 VI 2019].

74 The same opinion was also expressed by Internet users. On 10 March 2011, «iron» stated that it was: 'jeden z najlepszych polskich seriali wojenno-historycznych. Najlepsze role Pazury i Lubaszenki $\mathrm{w}$ ich karierze (potem tylko równali $\mathrm{w}$ dół - albo dali się zaszufladkować)' ['one of the best Polish war and history-themed series. The best roles of Pazura and Lubaszenko in their careers (then they barely levelled down - or they let themselves be pigeonholed)']. See: $h t t p: / / w w w . d w s . o r g . p l / v i e w t o p i c . p h p ? f=97 \& t=3416 \& s t$ $=0 \& s k=t \& s d=a \& s t a r t=25 A$; [accessed on: 11 VI 2019].

75 'Wszyscy, zarówno aktorzy jak i twórcy - pisano na jednym z portali internetowych - skupiali się na swojej pracy. Każdy z nich chciał, aby produkcja spełniała warunki filmu wojenno-szpiegowskiego, a nie była kolejnym pastiszem tego gatunku'. https://teleshow. wp.pl/pogranicze-w-ogniu-widzowie-ogladali-ten-serial-nie-tylko-dla-pieknych-aktorek6026635421340289g/5 [accessed on: 11 VI 2019].

76 'niezwykłą podróżą do coraz bardziej zapomnianej przeszłości'.

77 'niemalże filmowe arcydzieło'. https://teleshow.wp.pl/pogranicze-w-ogniu-widzowie-ogladali-ten-serial-nie-tylko-dla-pieknych-aktorek-6026635421340289g/7 [accessed on: 12 VI 2019]; User «iron» on 10 March 2011, said about the acting that 'Pogranicze jest jednym z najlepszych tego typu seriali? M.in. dlatego, że reżyserował je fachowiec i znawca tematu - Andrzej Konic - reżyser Stawki większej niż życie (i miał konsultantów historycznych z prawdziwego zdarzenia, a nie figurantów - pobierających kasę za nic - jak 'pseudokonsultanci' z 'Czasu horroru')' ['Borderline is one of the best series of this type? Among other reasons, because it was directed by a specialist and expert on the subject - Andrzej Konic - the director of More than Life at Stake (and it had real historical consultants, not figureheads - getting paid for nothing - like the 'pseudo-consultants' from 'Czas horroru' $\left.)^{\prime}\right]$. See: http://www.dws.org.pl/viewtopic.php?f=97\&t=3416\&st=0\&sk=t\&sd=a\&st art=25 [accessed on: 13 VI 2019]. 
and do broni), where the exchange of views took place, allows to conclude that the Internet users were interested in general questions on the one hand and on very specific issues on the other ${ }^{78}$. In an interview on the Kino Polska channel, Bogusław Wołoszański stated: 'The themes touched upon gained the series supporters as well as adversaries ${ }^{\prime 79}$; journalist Wojciech Krzyżaniak, while arguing that 'individually, there is nothing to admire ${ }^{80}$, admitted that the story in itself and its content are really engaging. [...] The camerawork had nothing to do with art, the greater the respect for the director and the whole crew for having managed to put together such poor elements into a series that you can now watch $[\ldots]$ and enjoy $i^{\prime \prime}{ }^{\prime 81}$. On the other hand, user 'Janowiak' assessed it in a very original way, stating that 'it's the script and the lack of shameful historical errors that save the series. [...] Anyway, I assess the series in the same way as scientific works are sometimes assessed: they may not be written in ravishing language (which would correspond to ravishing acting in this case), but at least without too many shameful mistakes, you don't fall asleep watching it and you can recommend ${i t^{\prime}}^{82}$.

78 Internet user «P-99» pointed, out, inter alia, ' problem z niedochodzącym kołnierzem' ['a problem with the collar'], which 'raz przylega innym razem odchodzi' ['lies flat, then comes off'] in Czarek Adamski's uniform, similarly to Colonel Kaleta, where he noticed 'kołnierz niedopracowany' ['the collar is done carelessly']. He also noticed service ribbons placed too low and rank signs badly sewn on in Adamski's uniform. See: https://forum. dobroni.pl/f/serial-pogranicze/26491 [accessed on: 13 VI 2019]; noticed inaccuracies related to the question of aviation'. See: http://www.dws.org.pl/viewtopic.php? $\mathrm{f}=97 \& \mathrm{t}=3416 \& s t=0$ \&sk=t\&sd=a\&start=75 [accessed on: 13 VI 2019]; On the other hand, «dak04» pointed out the 'plastikowy uchwyt do lampki z czasów kręcenia filmu' ['plastic lamp holder from the time of shooting'] which can be found on the bus in the episode devoted to operation 'Wózek'. See: http://www.dws.org.pl/viewtopic.php?f=97\&t=3416\&st=0\&sk=t\&sd=a\&st art=100 [accessed on: 13 VI 2019]; «Radomir» saw an Ursus C330 tractor in the second episode, and «Adaś» deciphered the scene at the Poznań Garbary station. See: http://www. dws.org.pl/viewtopic.php? $\mathrm{f}=97 \& \mathrm{p}=1790461$ [accessed on: 13 VI 2019].

79 'Ze względu na poruszaną tematykę serial zyskał zarówno zwolenników jak i wrogów'. https://teleshow.wp.pl/pogranicze-w-ogniu-widzowie-ogladali-ten-serial-nietylko-dla-pieknych-aktorek-6026635421340289g [accessed on: 13 VI 2019].

80 'pojedynczo nie ma się czym zachwycać'.

81 'opowieść, sama w sobie i jej treść, jest naprawdę zajmująca. [...] Zdjęcia nie miały nic wspólnego ze sztuka, tym większy szacun dla reżysera i dla całej ekipy, że udało im się, w sumie z takich bardzo słabych elementów, stworzyć serial, który ogląda się teraz [...] i odnajduje się $\mathrm{w}$ tym przyjemność'. https://teleshow.wp.pl/pogranicze-wogniu-widzowie-ogladali-ten-serial-nie-tylko-dla-pieknych-aktorek-6026635421340289g [accessed on: 13 VI 2019].

82 'serial ratuje scenariusz i brak karygodnych błędów historycznych. [...] Zresztą oceniam ten serial tak, jak ocenia się czasami prace naukowe - może nienapisane porywającym językiem (w tym przypadku chodzi o porywające aktorstwo), ale przynajmniej nie ma dużej ilości karygodnych błędów, nie zasypia się nad tym i można to 
Our considerations should now be summed up with the question whether the series is worth seeing, and if so, why? The reader has to give themselves an answer; however, in my opinion (and not only mine), it should be positive. First of all, the series made it to the classics of cinema, as the first picture to put the Second Polish Republic period in a comprehensive, chronological perspective. This is by no means synonymous with its history and the series did not have such ambitions. Andrzej Konic, showing (through selected episodes) the history of the pre-war 'Dwójka', presented a picture (incomplete by definition) of the interwar Poland in the background. We see mainly the military in it, but there are also elegant ladies and politicians. However, the heroes are by no means candy characters, they have doubts and moral dilemmas.

We could say they are people of flesh and blood. Bogusław Wołoszański said: 'However, nobody doubts that the production is simply a must see. - I think it's a very well-produced series bringing upon a topic that is rarely discussed, and it is worth it. Today, it is a kind of forgotten area in our history. Borderline on Fire shows that Poles were able to do a great job during the interwar period ${ }^{83}$. However, according to T. Formicki, the series should be watched ad nauseam by soldiers, state administration officials, and politicians, as if 'has set out very well what service to the state should look like and what the Polish reason of state means ${ }^{\prime 84}$. This is a difficult to controvert if a bit pompous statement. However, this does not change the fact that the analyzed series fully deserves the attention of viewers and... reviewers. Perhaps it should even, as a certain 'Baszybuzuk' suggested, be remade 'in the style in which the Americans refresh their drama series from a similar period's5.

(translated by LINGUA LAB)

polecić'. http://www.dws.org.pl/viewtopic.php?f=97\&t=3416\&st=0\&sk=t\&sd=a\&start=25 [accessed on: 14 VI 2019].

83 ‘Jednak nikt nie ma wątpliwości, że tę produkcję po prostu trzeba obejrzeć. - Sądzę, że jest to bardzo dobrze zrealizowany serial, który podejmuje temat rzadko podejmowany, a jest tego warty. Dziś to jest taka zapomniana dziedzina w naszej historii. Pogranicze wogniu pokazuje to, że Polacy potrafili zrobić kawał dobrej roboty w czasie dwudziestolecia międzywojennego'. https://teleshow.wp.pl/pogranicze-w-ogniu-widzowie-ogladali-tenserial-nie-tylko-dla-pieknych-aktorek-6026635421340289g [accessed on: 14 VI 2019].

84 'w tym serialu bardzo dobrze wyeksponowano jak powinna wyglądać służba państwu i czym jest polska racja stanu'. F. Formicki, op. cit., p. 17.

85 'w stylu w jakim Amerykanie odświeżają swoje produkcje serialowe z podobnego okresu'. http://www.historycy.org/historia/index.php/t66370.html [accessed on: 14 VI 2019]. 


\section{REFERENCES}

\section{Archival sources}

Archiwum Akt Nowych:

Naczelny Zarząd Kinematografii, ref. no. 5/45.

Ośrodek Dokumentacji i Zbiorów Programowych TVP S.A. Dział Dokumentacji Aktowej: Państwowa Jednostka Organizacyjna 'Polskie Radio i Telewizja' w Likwidacji, ref. no. 2149/30, vol. 22; 2149/30, vol. 27; 2149/30, vol. 29; 2149/30, vol. 55.

\section{Papers and magazines}

Głogowski K., Duchowa siła armii, ‘Polska Zbrojna' 1 October 1992.

Formicki T., 'Pogranicze w ogniu', czyli legenda wielkiej 'Dwójki', 'Myśl Polska' 12 October 2008

(M.W.), Koniec 'Pogranicza w ogniu', 'Antena' 6-12 February 1992.

Mokrzycka M., 'Pogranicze w ogniu' w Warszawie, 'Express Wieczorny' 26 August 1987.

Najpierw 'Czas honoru' potem czas na czarne plamy [Interview with Andrzej Paczkowski], 'Gazeta Wyborcza' 29 November 2013.

OPAL, Pogranicze w ogniu, 'Sztandar Młodych' 11 January 1993.

OPAL, Pogranicze w ogniu, 'Sztandar Młodych' 8 February 1993.

Pogranicze w ogniu, 'Antena' 29 August - 4 September 1992.

Strzyga Lucjan, Kulisy serialowych przebojów reżysera Andrzeja Konica, in: http://www.gazetawroclawska.pl/artykul/324957,kulisy-serialowych-przebojow-rezysera-andrzeja-k onica,id,t.html [accessed on: $20 \mathrm{~V}$ 2019].

\section{Studies}

Chutnik S., Czas honoru jako poppolityka historyczna, in: Seriale w kontekście kulturowym. Historia i polityka, eds. M. Cuchmińska, A. Naruszewicz-Duchlińska, Olsztyn 2014.

Machcewicz P., Spory o historię 2000-2011, Kraków 2012.

Ćwięk H., W tajnej stużbie II Rzeczypospolitej. Wywiad Polski wobec Niemiec w latach 19181939, Częstochowa 2009.

Kostro R., Merta T., Wstęp, in: Pamięć i odpowiedzialność, eds. R. Kostro, T. Merta, KrakówWrocław 2005.

Krawczyk-Łaskarzewska A., O telewizji i dyskursie telewizyjnym - historia, fikcje, rzeczywistość, in: Seriale w kontekście kulturowym. Historia i polityka, eds. M. Cichmińska, A. Naruszewicz-Duchlińska, Olsztyn 2014.

Merta T., Pamięć i nadzieje, in: Pamięć i odpowiedzialność, eds. R. Kostro, T. Merta, KrakówWrocław 2005.

Misiak A., Kinematograf kontrolowany. Cenzura filmowa w kraju socjalistycznym i demokratycznym (PRL i USA). Analiza socjologiczna, Kraków 2006.

Nacher A., Serial 2.0 - model do składania, in: Post-soap. Nowa geberacja seriali telewizyjnych a polska widownia, eds. M. Filiciak, B. Giza, Warszawa 2011.

Witkowski Cz., Majowy zamach stanu. Czy działania podjęte przez piłsudczyków były w petni zaplanowane, czy też w dużym stopniu okazały się działem przypadku? Wojskowy rokosz Pitsudskiego, Warszawa 2016.

Wróblewska A., Studio Filmowe (dawniej Zespót Filmowy) 'Perspektywa', in: http://www.akademiapolskiegofilmu.pl/pl/historia-polskiego-filmu/studia-filmowe/studio-filmowedawniej-zespol-filmowy-perspektywa/6 [accessed on: 23 V 2019]. 


\section{Web sources}

http://www.dws.org.pl

https://forum.dobroni.pl/f/serial-pogranicze/26491

http://www.historycy.org/historia/index.php/t66370.html

https://pl.wikipedia.org/wiki/Polityka_historyczna

https://pl.wikiquote.org/wiki/Pogranicze_w_ogniu

http://www.telemagazyn.pl/serial/pogranicze-w-ogniu-552417/odcinki/

https://teleshow.wp.pl/pogranicze-w-ogniu-widzowie-ogladali-ten-serial-nie-tylko-dlapieknych-aktorek-6026635421340289g

\section{Filmography}

Czarne chmury [Black Clouds], Poland, 1973, dir. A. Konic.

Czas honoru [Time of Honour], Poland, 2008-2014, dir. M. Kwieciński, M. Rosa, W. Wójcik, G. Kuczeriszka, W. Krzystek, M. Rogalski.

Kolumbowie [Columbuses], Poland, 1970, dir. J. Morgenstern

Pogranicze w ogniu [Borderline on Fire], Poland, 1992-1993, dir. A. Konic

Stawka większa niż życie [More Than Life at Stake], Poland, 1967-1968, dir. A. Konic, J. Morgenstern.

Ziemia obiecana [The Promised Land], Poland, 1974, dir. A. Wajda.

\section{STRESZCZENIE}

Prezentowany tekst, którego kanwą jest dwudziestocztero odcinkowy serial historyczny pt. 'Pogranicze w ogniu' to analiza dyskusji, jaka do dnia dzisiejszego toczy się na temat tego serialu, ale i obrazu Drugiej Rzeczpospolitej. Naczelną przesłanką było pokazanie miejsca i znaczenia $\mathrm{w}$ dyskursie publicznym dwudziestolecia międzywojennego - epoki, która nieodłącznie kojarzy się z Józefem Piłsudskim, a która współcześnie uległa znacznej mitologizacji. Wynikiem tych rozważań jest konstatacja, że, przynajmniej dla entuzjastów, historia międzywojnia nadal cieszy się zainteresowaniem, a jednym z elementów je podtrzymującym był, i jest, analizowany serial.

Słowa kluczowe: Andrzej Konic, Druga Rzeczpospolita, serial historyczny, dwudziestolecie międzywojenne, stosunki polsko-niemieckie, Oddział II Sztabu Generalnego, Abwehra, dyskurs, polityka historyczna

\section{ABOUT THE AUTHOR}

Marek Sioma (1971) - PhD with 'habilitation, Professor at the Maria Curie-Skłodowska University in Lublin, works at the Department of Methodology and Research on the 20th and 21st centuries. In 1995, he graduated in history from the Maria Curie-Skłodowska University. He obtained his PhD title in 2002, and the habilitation degree in 2014. He conducts scientific research on the Piłsudski camp, focusing on its elites, breakdown and the youth movement (Legion Młodych). He has published and edited 3 monographs. Author of 45 scientific articles and a number of smaller texts. In 2009-2015, secretary of the Lublin Branch of the Polish Historical Society. President of the Historical Olympics in the Lublin district since 2009, Director of the Institute of History at the UMCS from 2016 to 2019. 